\title{
Far Tail or Extreme Day Returns, Mutual Fund Cash Flows and Investment Behaviour*
}

\author{
David A. Burnie \\ Haworth College of Business \\ Western Michigan University \\ Kalamazoo, MI \\ USA \\ e-mail: david.burnie@wmich.edu \\ Adri De Ridder \\ Gotland University \\ Visby, Sweden \\ e-mail: adri.deridder@hgo.se
}

February 23, 2009

\footnotetext{
* We have benefited from comments from Dick Brealey, Per Carleberg, Elroy Dimson, Susan Elkinawy, Anthony Neuberger, Jonas Råsbrant and Lars Vinell. Financial support from the Marcus and Amalia Wallenberg foundation is gratefully acknowledged.
} 


\title{
Far Tail or Extreme Day Returns, Mutual Fund Cash Flows and Investment Behaviour
}

\begin{abstract}
This study examines the frequency of extreme trading days and investment behaviour in Sweden. We show that the frequency, as well as the magnitude of extreme trading days has increased over time. We also show that the frequency of extreme trading days in a year is positively correlated to the frequency the preceding year. Furthermore, we show that aggregate cash flows into equity and bond funds are unrelated to risk measured by standard deviation of return. Our findings show that investors, individuals as well as corporations, use simple passive investment strategies and hence, do not believe in market timing or wish to risk capital on capturing far tail or black swan type returns.
\end{abstract}

JEL classification: G11; G14; G32

Keywords: Volatility, Distribution, Extreme Value, Stock Market 


\section{Introduction}

The widely-held view among most individual investors is the relationship between expected return and risk where risk is the uncertainty that the realized return will not be equal to the expected return. On the other hand, neo-classical financial theory suggests that risk is quantified by the variability of returns (standard deviation) or by the relative volatility in the returns (beta). Also, portfolio theory determines the combination of risk and return that achieves the highest return for a given level of risk where the combination of systematic and unsystematic risk is defined as the total risk that the investor bears. An alternative or supplementary view of risk focuses on analyzing outliers in the return distribution, using extreme value theory, an approach introduced already in the 1960s by Mandlebrot (1963).

More recently, alternative definitions of risk have been documented which shows that investors do not use traditional definitions of risk but instead apply explanations based on some type of bounded rationality (overconfidence), see Benartzi and Thaler (1995) and Barberis et al. (1998). Within this broad framework of risk are many subsidiary measures used by investors. Veld and Veld-Merkoulova (2008) find stock investors place heavy reliance on semi-variance (the downside of risk) as their primary measure of risk, in a survey of Dutch investors. While all investors used more than one measure of risk, bond investors favoured the probability of loss as their number one measure. In all cases these downside risk measures were predominant. Previous studies have thus not been able to fully explain how individual investors define and respond to different definitions of risk.

Over the last decade, empirical studies with a focus on extreme day returns and extreme value theory have grown substantially as the returns on these days have had a significant valuation impact. In general, extreme day returns can be characterized as follows: a) they occur rarely, b) they are indeed associated with large extreme values, and c) they are difficult to predict. Investors view losses more strongly than gains; extreme day negative returns may thus have a greater anchoring effect. Some have characterized far tail returns or extreme 
returns as 'Black Swans' (see Bogle (2008), Estrada (2008)). Investors have difficulty selling their losses and are much quicker to sell winners as shown by Shefrin and Statman (1985); De Bondt (1998) argued that the initial investment is a "highly salient reference" point for investors. The survey study by Veld and Veld-Merkoulova showed consistent behaviour with anchoring on the initial investment.

Prior empirical studies have also shown that daily stock market returns, in contrast to monthly or longer horizons, display non-normal distributed features. Instead, the distribution seems to be leptokurtic, skewed and with non-stationary returns. Even if a fat tailed distribution is a clear departure from the generally accepted view that returns are normal distributed, they are consistent with financial theory. For instance, the concerted movement of large groups of investors into or out of a particular stock, industry of companies, or even an entire market at the same point in time can result in the clustering of extreme events. Thus, this herding can cause investors to buy or sell a stock based on the "feel" of the herd rather than on fundamentals, see De Bondt and Thaler (1985) and Barber and Odean (2002). The evidence of fat tails is also consistent with the asymmetric response to news. For instance, the level of standard deviation in stock returns across bull and bear markets has been examined by Hardouvelis and Theodossiou (2002) who report higher volatility in bear compared to bull market periods as lower asset prices are associated with higher uncertainty but also that higher uncertainty and price sensitive information implies higher volatility. In other words, market participants have more difficulties analyzing price sensitive information in a bear than in a bull market, see also French and Roll (1986).

One advantage to define risk, based on extreme day returns, is the opportunity to decompose the volatility of daily extreme day returns into a negative and a positive component. The decomposition into downside and upside extreme day risk allows for 
inspection of investors reaction to these two components. In addition, implications for portfolio rebalancing and or trading may be evident.

In this paper, we examine the frequency of extreme-day returns as well as returns surrounding these days on the Stockholm Stock Exchange (SSE) in Sweden. We study flows to equity and bond funds by individual investors and investigate whether these flows are sensitive to the overall risk on the market as well as the frequency of extreme-day returns. We analyze individual investors' response to the overall return on the market because, at least in Sweden but also in many other countries, the shift from defined benefit to defined contribution pension schemes has caused more attention from individuals towards investments in financial assets. Market value changes (whether realized or paper gains) are an important consideration for retirement packages as at least some portion of the equity holdings must be converted to annuities.

Broadly speaking, we follow the methodology proposed by Jones et al. (2004) and extend prior literature by analyzing the frequency of extreme day returns by calendar time but also advance prior studies using event-study methodology surrounding extreme dates. We investigate and model the relationship between flows to mutual funds of stocks and bonds from individuals as well as corporations and use several risk metrics. In this analysis, it is important to recognize that in Sweden, rebalancing (moving from equity to bonds and vice versa) in most cases will cause a taxation of capital gains, in other words, an individual can not rebalance his portfolio without tax consequences except inside of self-directed retirement plans.

By investigating the frequency of extreme day returns in detail, this paper advances to the literature on extreme days, volatility and investor reaction to downside and upside risk. It also contributes to the literature on the determinants of flows into the mutual fund industry and investment behaviour by individual and corporate investors. 
We find strong evidence that the frequency of extreme-day returns has increased over time. For the overall sample period, we find that extreme-day returns, defined as a trading day with an absolute return (continuously compounded) in excess of $1.5 \%$, constitute $7.43 \%$ of all trading days. After partitioning our extreme-day returns into negative (lower tail) and positive returns (upper tail), we find that they are roughly evenly distributed but that negative returns are associated with a higher variability (standard deviation) compared to positive returns. We also study in detail the overall market return surrounding trading days with positive and negative extreme-day returns respectively. We find that mean cumulative market return (measured over the trading period days $0,+20$ ) is negative following a negative extreme day returns but remains positive for positive extreme day returns. We also document a positive correlation between the frequency of extreme days current and the preceding year. While the overall market reacts to extreme day risks, our cross-sectional analysis suggests no significantly differences in flows to equity and bond funds related to standard definitions of risk. In summary, our analysis indicates that Swedish individual investors do not change their asset allocation based on various definitions of risk for equity funds but that bond fund flows are impacted by the frequency of extreme days. While we have no direct evidence, this may be due to tax-rules that "fence in" possible rebalancing strategies.

The rest of the paper is organized as follows. In Section 2, we describe the data, some preliminary findings and methodology used in this paper. Section 3 presents the findings of extreme-day returns, returns surrounding these days, correlation in the frequency of extreme day returns and the impact of various risks on flows to equity and bond funds. Section 4 concludes.

\section{Data, Preliminary Findings and Methodology}

The data of daily market returns used in this study comes from two sources: (1) a handcollected set of overall market returns and (2) a time-series returns. In this paper, we classify 
the daily market return as an extreme return if the absolute percentage return is greater than or equal to $1.5 \%$ (see page 9, 10 for discussion). Accordingly, the examination of extreme day returns on the SSE in Sweden shows that the frequency has increased over time. For the overall sample period, we find that extreme day returns on average constitute $7.43 \%$ of all trading days. However, this frequency varies substantially, from $0.70 \%$ in the 1950 s to $15.23 \%$ for the $1990 \mathrm{~s}$. The increase in volatility is consistent with the increase in crosssectional variation found by McEnally and Todd (1992) from the 1950's to the 1980's and by Xu and Malkiel (2003) across the US markets from the 1950's to 1998.

As extreme risk is increasing over time as total variation is, the extreme risk may be a contributing factor. While much discussion has taken place in the finance literature about diversification over time, perhaps extreme day returns are any example of why diversification across assets is important. Guo and Darnell (2005) provide an overview of the diversification across time arguments and use three time series models to show that stock returns are consistent with a mean-reversion process and exhibit better relative risk reduction over time than T-bills or T-bonds. In general, it may be valuable to diversify across time for bonds or equities, but one must be diversified across assets as individual asset value can go to zero. Extreme day return in an asset may also include total loss, the reasons why extreme day returns occur and their timing is not clear, nor controllable.

Our data of daily return for the overall market on the SSE cover the 67-year period 1939-2006. In all, we use a total of 17,733 daily observations for our sample period. Due to lack of one time series, reflecting the overall market return, two different time series have been compiled and then merged. For the period 1939 to 1972 the Jacobson \& Ponsbach, $(J \& P)$, index is used. This index is an equal weighted index of shares listed on the SSE and is also the oldest available index with daily data reflecting the overall return on the market. From 1973 to 2006 the business magazine Affärsvärldens Generalindex, (AFFGX), a value 
weighted index of shares listed on the SSE, is used. Both these series reflect only price changes and thus exclude cash dividends. ${ }^{1}$ The $J \& P$-index data have been hand-collected from daily editions of the Swedish newspapers Dagens Nyheter and Svenska Dagbladet available from the National Library (Kungliga Biblioteket, KB) in Stockholm. Data for the $A F F G X$-index have been collected from the homepage of the business magazine Affärsvärlden.

The largest price decline in our sample occurred on Thursday, October 29, 1987, when the market index dropped from 44.0632 to 40.2126 which corresponds to an arithmetic percentage return of $-8.7388 \%$. However, to return to the original level, a price appreciation of $9.5756 \%$ is required. In other words, the arithmetic return is not symmetric. We can obtain this symmetry by computing the geometric instead of the arithmetic return. In this case the price drop corresponds to a geometric return of $-9.1444 \%$ which is symmetric as it will bring the index to its original level when a continuous compounding is performed. Thus, our study, as well as in most studies of short-term share price volatility, compute and use daily continuously compounded returns as follows (where the price level of the index, $P$, is the daily closing value at day $t$ and $t-1$ respectively):

$$
R=\ln \left(\frac{P_{t}}{P_{t-1}}\right) .
$$

\footnotetext{
${ }^{1}$ We are concerned about potential measurement errors when we pool together an equal and a value weighted time series of market returns on the SSE. Our analysis also shows that the relative importance of a single firm on total market value has increased since the 1990s. For instance, in 1990 and 1995, the largest firm represented $5.4 \%$ and $12.1 \%$ of total market value. To examine the sensitivity of our analysis of extreme day returns prior 1973, we constructed a value weighted index for the 30 largest firms (rebalanced, and based on market cap every year) on the SSE for the period 1945-1972 and analyzed the correlation between the value and the equal weighted series. The outcome of this analysis shows a marginal difference between the series. Mean (standard deviation) of the equal weighted index is $18.6 \%(21.0 \%)$ and $16 \%(21.6 \%)$ for the value weighted index. The correlation coefficient between the series is, 0.9608 for the period 1945-1972 and suggests that the transition into the value weighted series from 1973 should not be of importance. In summary, we have no reason to believe that the use of two times series will have any impact on our analysis of extreme day returns, specifically as the increase of extreme days took off after 1973.
} 
Unfortunately, no precise definition of an extreme day return is provided in the literature or in previous research. Jones et al. (2004) define, and use for their sample, an extreme day as a trading day with an absolute daily percentage change greater than or equal to $1.5 \%$ whereas Pactwa and Prakash (2004) use three different definitions, 2\%, 3\% and 4\% respectively. Thus, prior research seems to define an extreme day with a return which varies between $1.5 \%$ and 4\%. For our overall sample period, $80.1 \%$ of all daily returns are within one standard deviation from the mean and $94.9 \%$ are within two standard deviations from the mean. If we apply an absolute level of $2 \%, 3 \%$ and $4 \%$ for our full sample period, the number of extreme days will constitute $3.6 \%, 1.2 \%$ and $0.4 \%$ of total trading days for our sample. After this examination, we decided to use an absolute level of $1.5 \%$ as the definition of an extreme day. In our analysis we classify an extreme day return with a value of $-1.5 \%$ or less as located in the lower tail while returns with a value of $1.5 \%$ or more are located in the upper tail.

\section{Results}

\section{Distribution and Summary Statistics of Extreme Day Returns}

Table 1 provides summary statistics for our sample over the period 1939-2006. Panel A provides the distribution of daily logarithmic returns. As shown, 3.67\% and $3.76 \%$ of the returns are located in the lower and upper tail respectively.

Panel B of Table 1 gives summary statistics for our observations. A few important points can be noticed with respect to our observations. Overall, the mean (median) logarithmic daily percentage change is $0.033 \%(0.045 \%)$. Thus, our data do not support the general view that returns are normally distributed around the mean. Instead, we find evidence of a negatively skewed distribution with fat tails. ${ }^{2}$ As reported, we also see that the mean (median) logarithmic daily percentage change is $-2.381 \%(-2.011 \%)$ for negative extreme day

\footnotetext{
${ }^{2}$ Further analysis shows that 21 trading days report a return of $-5 \%$ or less and 19 trading days report a return equal to or higher than $5 \%$. Actually, $1.77 \%$ of the observations are outside a +/- 3 standard deviation range.
} 
returns and $2.279 \%(1.957 \%)$ for positive extreme day returns. Also, standard deviation in these returns is higher for negative $(1.048 \%)$ compared to positive $(0.970 \%)$ returns. The lowest return in the lower tail is $-9.144 \%$ and represents October $29^{\text {th }} 1987$ whereas in the upper tail, October $12^{\text {th }} 1998$ is accompanied with the highest return, $9.816 \%$.

Panel C of Table 1 shows the distribution of our returns. As shown, and not surprisingly, we see a substantial dispersion in the returns. For instance, the $5 \%$ percentile values are $-4.207 \%$ for the lower tail and $1.535 \%$ for the upper tail. In a similar way, the $95 \%$ percentile has a value of $-1.524 \%$ and $4.035 \%$ respectively. This confirms our earlier finding that the distribution of returns is skewed.

\section{Negative versus Positive Extreme Days}

Panel A of Table 2 shows the frequency of extreme day returns for the full sample period, 1939-2006, as well as for the periods 1940-49, 1950-59, 1960-69, 1970-79, 1980-89, 1990-99 and 2000-2006. As shown, the frequency of extreme day returns, defined as number of extreme day returns divided by trading days for each sub-period and expressed in percent, varies between $0.70 \%$ for the period $1950-59$ to $15.23 \%$ for the period 1990-99. Note, however, that in the most recent period, 2000 to 2006, shows the highest frequency of extreme day returns, $20.43 \%$. Also, there is a strong time trend in the frequency of extreme day returns in our sample. For instance, over the last 25 year period 1982 to 2006 (not reported), 18 of the calendar years have a frequency of extreme day returns higher than the mean for the overall sample period. Actually, for this specific time period, the mean percentage of extreme days is $16.19 \%$ which is more than twice the figure for the overall sample period. The increase in the frequency of extreme day returns and consequential risk increase highlights the concern that investors should have about portfolio value and rebalancing, particularly when negative extreme days occur. Column 4 and 5 in Panel A of 
Table 2 gives the minimum and maximum value for our extreme day returns of $-9.144 \%$ and 9.816\%. In Panel B, we sort the extreme days by calendar months. As reported, the frequencies of extreme day returns seem to coincide when most firms listed on the SSE release their financial results for the business year (in January), but also the half-year and 9months financial report (September and November respectively). ${ }^{3}$ Finally, Panel C sorts the extreme day by weekdays where our data set suggests that an extreme day is slightly more likely to occur on Mondays and less likely on Friday. Trading on Saturdays ceased on May $27^{\text {th }} 1961$.

We explore the magnitude of extreme day returns over our sample period by using a simple time-series analysis of our data. As can be seen from Figure 1, the data support our earlier findings that the frequency of extreme days has increased over time. As can be seen from the figure, the frequency of extreme days started to increase in the beginning of the 1980s and reached high levels in the calendar years 2000, 2001 and 2002 where the percentage of extreme days was $39.04 \%, 43.20 \%$ and $37.60 \%$ of all trading days respectively. The high level of uncertainty associated with the "dot.com technology" led market collapse and highlighted the extreme day return risk. Since then, the proportion of extreme trading days has declined to roughly $10 \%$ of the trading days. The horizontal line in Figure 1 show the median value $(4.43 \%)$ for the full sample period and reinforce our finding that since the beginning of the 1980s, the frequency has indeed increased. Additional evidence of the content of the extreme day returns is provided in Figure 2 which decomposes the percentage of extreme day returns in a year into the percentage of negative and positive returns. As the graph indicates, it is obvious that a higher proportion of the extreme days is associated with a negative return. To be more specific, in the years 2000, 2001 and 2002, negative extreme day

\footnotetext{
${ }^{3}$ We also investigated the relationship between the overall return on the market and for ex-dividend days to examine if ex-dividend days are associated with a negative extreme date return. No such relationship was identified. Also, as indicated by Panel B in Table 2, the frequency of extreme days in April and May (when most stocks listed on the SSE goes ex-dividend) are not exceptionally high.
} 
returns represented $19.9 \%, 22.8 \%$ and $22 \%$ of all trading days. Thus, on average, and during this period, one trading day in a week is associated with a price drop less than or equal to $1.5 \%$ of the market index.

The conclusion drawn from Table 2 and Figure 1 and 2, can be summarized as follows. First, there is strong evidence that the frequency of extreme day returns have increased over time. Second, even if the distribution of negative and positive extreme day returns is fairly evenly distributed over the sample period the magnitude of negative extreme day returns is greater than positive extreme day returns. Third, our results suggest that there is a calendar pattern in the distributions with high frequency of extreme day returns in months when firms present their financial results. Extreme day returns are approximately evenly distributed across calendar days with Fridays being the exception.

\section{Market Performance Post Extreme Day Return}

Extreme day returns are unusual market events which may have lasting or directional influence on the overall market. We examine the mean and cumulative return on the market portfolio after an extreme date to further investigate stock returns and possible momentum effects following an extreme date. In our cumulative return analysis we first compute the average return for a total of 651 negative and 666 positive extreme dates for the first sixty trading days after the extreme date. ${ }^{4}$ Next, from these returns we cumulate the average returns over the three window periods, periods $(0,10),(0,20)$ and $(0,60)$. As Figure 1 indicates that the frequency of extreme dates has increased since the 1980s, and we have reason to believe different perceptions of these events, we examine the returns for two 25 year periods, 1957 1981 and 1982-2006, respectively as well as for the overall sample period.

\footnotetext{
${ }^{4}$ We also separated this analysis into two parts, whether an extreme date occurred within the first five trading days following the extreme date or not. The results are quantitatively the same.
} 
Table 3 presents the mean and median market returns for our overall sample period but also for our two sub periods. We report the cross-sectional mean (median) of market returns and mean (median) cumulative market returns for different event windows following extreme dates located in the lower and upper tail. Panel A, representing the period 1939-2006, reports that the average return on day 1 , is $-0.142 \%$ for returns located in the lower tail and also statistically significant at the $5 \%$ level $(t$-statistic $=-9.90)$. For extreme dates located in the upper tail, the average market return is $0.319 \%$ on day 1 and it is also statistically significant at the $1 \%$ level $(t$-statistic $=50.60)$. Panel A shows also that for extreme dates located in the lower tail and during the first trading week, four of five trading days have a negative mean return but only two negative days are statistically significant. For our observations located in the upper tail, mean market daily return remains positive for all trading days in the subsequent week but are only statistically significant different from zero on days one and two.

In Panel B and C we report the findings for the period 1957-1981 and 1982-2006. Generally speaking, the data shows that the mean return immediately following a negative extreme day (day 1) improved from $-0.202 \%$ for the $1957-1981$ period to $-0.111 \%$ for the 1982-2006 period. Mean return following a positive extreme date fell from $0.373 \%$ and to $0.274 \%$ for the $1957-1981$ and the $1982-2006$ periods respectively.

In Panel $\mathrm{D}$ we report the mean cumulative market return for three different event windows, $(0,10),(0,20)$ and $(0,60)$. For the overall sample period, and for returns located in the lower tail, the mean cumulative return exhibits an increasing pattern of $-2.194 \%,-1.854 \%$ and $0.094 \%$ for our three windows. The estimates are also statistically significant. For returns located in the upper tail we see a monotonic and a statistically significant increase in the returns for the three windows with cumulative returns of $2.912 \%, 3.562 \%$ and $6.074 \%$ respectively. ${ }^{5}$ Based on these findings, the evidence suggests that price changes in the overall

\footnotetext{
${ }^{5}$ Results are substantially similar when we use event windows $(0,30),(0,40)$, and $(0,50)$.
} 
market return following extreme dates exhibit a momentum pattern and is pronounced following positive extreme date returns. The results for the two sub-periods are consistent with the overall period with negative extreme day cumulative returns approaching zero and the positive extreme day cumulative returns increasing in value. The negative values appear to be reverting towards zero while the positive values do not exhibit reversion within the 60 days.

\section{Market Direction and Correlation Tests}

An alternative way to examine the overall market returns following an extreme date is to compare the stock market return with the extreme date return. Hence, we address two questions, (a) is there a correlation in returns following extreme days and (b) is there a spillover effect of frequency of extreme days from one year to another year? The first question is answered by examining the relationship between overall market returns and extreme date returns by using a simple OLS-regression model.

Table 4 shows the results of our regression analysis of extreme market return (the independent variable) on the overall market return (the dependent variable). In our analysis we confine the period to five trading days after the extreme day return, thus we examine the returns in the window $t+1$ to $t+5$. We report our findings for three periods, the full sample period 1939-2006 (Panel A) and the sub periods 1957-1981 (Panel B) and 1982-2006 (Panel C) respectively. Our regression results indicate some interesting inferences.

As reported in Panel A, the estimated negative coefficient in the first two trading days following extreme dates located in the lower tail are statistically significant at the $5 \%$ level $(t$ statistic $=-4.08$ and -2.07 respectively) but statistically insignificant for returns located in the upper tail. In Panel B, the estimated coefficient is negative and statistically significant for the second trading day after a negative extreme day. For positive extreme dates, we document a 
negative correlation for the first trading day after the extreme date indicating that average positive returns decline after the positive extreme day over the period 1957 to 1981 . In Panel C we report results for the period 1982-2006. As shown, the estimated negative coefficients for the first two trading days following a negative extreme date are statistically significant. No such relationship can be identified for returns located in the upper tail.

Overall, our results indicate that market participants react differently on positive and negative extreme date returns. After a negative extreme day return the market returns will improve with less negative returns. This finding is also consistent with our results presented in Table 3. These results may suggest either a trading or rebalancing rule; the better time to rebalance the portfolio and minimize risk of loss if a negative extreme day occurs is between 20 and 60 days based on the cumulative market returns and at anytime if a positive extreme day occurs under the condition that the sooner rebalancing occurs the less gain will be captured under a positive extreme day period (greatest percentage gain occurs in the first 10 days). Alternatively if one is trading, then purchase of securities should provide the most return if bought on the extreme day and held for at least two days for negative extreme days given the negative correlation associated with day $t+1$ and $t+2$ as reported in Table 4 . On positive extreme days purchases held for several periods yield significant returns (see Panel D, Table 3).

Next, we estimate the predictive power of frequency of extreme dates in the past to predict the future frequency of extreme dates. We use a simple OLS-regression model where the dependent variable is frequency of extreme days, defined as the ratio of the number of extreme days to the number of trading days in year $t$, and our independent variable is the same variable but for the preceding year $(t-1)$ as described in equation (2).

$$
\operatorname{Freq}_{X \text { days }, t}=a+b\left(\text { Freq }_{X \text { days }, t-1}\right)+e .
$$


Table 5 reports estimation results for our OLS-model and for three sub-periods. As indicated by the estimated regression coefficient, we obtain statistically significant estimates for the three sub-periods, 1940-1961, 1962-1983, 1984-2006 and for the overall sample period 1940-2006. The estimated coefficients are all positive suggesting a positive but less than unity change year to year or trend adjustment in frequency of extreme day returns. Furthermore, the adjustment coefficient (or slope) has increased over time from the first to the third period as indicated in Figure 1 and 2. These results confirm that the frequency of extreme days in the current year is correlated with the frequency the prior year and thus exhibits some predictive power. The $\mathrm{R}^{2}$ shows that the $29.7 \%$ of the first period of frequency of extreme days is explained by the prior year frequency of extreme days; $18 \%$ is explained in the second period, $32 \%$ is explained in the third period and $56.8 \%$ is explained by the prior year extreme day frequency over the full sample period. Additional regression tests were conducted on each decade (10 observations) with 1 period (1940-49) having a significant slope coefficient at the 5\% level (not reported). The three sub-periods were also estimated shifting the data to begin with 23 observations in 1940-1962 and then 22 and 22 observations for the last two periods. All slope coefficients were positive (not reported), but only the first and third period were significant at the 5\% level or higher. While these results are not identical to the previous results there is a high degree of consistency between the estimates.

An alternative model was employed to see how the percentage change of extreme days change from year to year, thus we use the following model:

$$
\Delta F r e q_{X \text { days }, t}=a+b\left(\Delta F r e q_{X \text { days }, t-1}\right)+e .
$$

Model (3) was estimated in the same time manner as stated for model (2). The slope coefficients were all negative with 2 significant at the $5 \%$ level or better over the decades. The reverse signs are expected as this model uses the change in percent of the frequency. While in the three sub-periods and 1941-2006 all coefficients are negative, the results are significant 
only in the second sub-period. The results indicate a modest relationship between the percentage change in frequency of extreme day returns year to year. The limited amount of significance for model (3) favours the use of model (2).

Next, we analyze the relationship between frequency of extreme days and large negative price changes on the stock market. Some authors argue that stock market volatility is different in bull and bear markets. On the other hand, there seems to be no general accepted definition of a bull and bear market. For instance, a bull market is often characterized by an extended period of rising security prices. Jones et al. (2004) define a bull market where stock prices for a calendar year increase by more than $40 \%$ and a bear market when the overall return is less than $-15 \%$. In our examination, we define a bear market as a calendar year when the overall return on the market drops by more than $-10 \%$. To check whether a bear market year implies more extreme days we add a dummy variable to our basic model where we regress the frequency of extreme days in a year on the frequency of extreme days in the prior year. More specifically, the dummy variable takes the value of 1 if the year is classified as a bear year and zero otherwise. Applying this model to our full sample period 1940-2006, yield the following results ( $t$-statistics within parentheses).

$$
\text { Freq }_{X \text { days }, t}=0.0199 * *+0.8054 * * *\left(\text { Freq }_{X \text { days }, t-1}\right)-0.0312\left(\text { Bear }_{t-1}\right)+e
$$

As shown, the estimated coefficient for a bear market is negative, does not have the predicted sign and is not statistically significant $(t$-statistic $=-1.21)$. The frequency of extreme days is unrelated to the bear market condition of the prior year. The negative sign suggests that if a bear market occurs, the frequency of extreme days in the following year is expected to marginally decrease (estimated slope coefficient $=-0.031$ ). The coefficient on frequency of extreme days in t-1 increases slightly to 0.81 (from 0.75 , see Table 5) and continues with 
strong significance $(t$-statistic $=8.79)$. The addition of the bear market dummy variable has increased the noise in the model while increasing $\mathrm{R}^{2}$ slightly to 0.578 but decreasing the adjusted $\mathrm{R}^{2}$ to 0.565 . This relatively simple model explains more than half of the variation in the frequency of extreme day returns but adding the $-10 \%$ bear term is not valuable.

In addition to our definition of bear market, we also use a $-15 \%$ and $-20 \%$ market return as a definition of a bear market. The results of this approach indicate that our estimated coefficient for bear market are still statistically insignificant, -0.0435 ( $t$-statistic -1.47$)$ for the $-15 \%$ bear condition and $-0.0584(t$-statistic $=-1.51)$ for the $-20 \%$ bear condition. The low frequency of events in the regressions may explain the lack of significance. There are 9 of 67 years that are defined as bear markets using the $-10 \%$ decline; 6 of 67 for the $-15 \%$ decline and only 3 of 67 using the $-20 \%$ decline as the bear market definition. Large market changes may directly relate to the increase in frequency of extreme day returns, whether large positive (bull) and negative (bear) changes, but this can not be ascertained in these annualized returns. Overall, our robustness check, and the predicted sign of the estimated coefficient are not consistent with the results in Jones et al. (2004) and statistically provides no indication of a spill-over effect in the frequency of extreme days from bear-market years.

\section{Corporate and Individual Investor Allocation Behaviour}

One important field, related to risk and return, is whether households change their investment behaviour due to market conditions. Prior literature related to investments by individuals report that investment decisions are not only caused by asset allocation decisions but also to disposition effects i.e. to hold losing and selling winning stocks, see Odean (1999) and Shefrin and Statman (1985). Furthermore, many investors use simple investment rules as a tool to protect their wealth and exhibit irrational behaviour. Perhaps, the most important rule in Sweden is the "stay the course"-strategy together with investing a fixed amount in a fund at 
a regular interval (monthly savings by dollar cost averaging). Consequently, the investor buys more (less) units when the price is low (high). Thus, one interesting avenue is to investigate the relationship between flows to equity and bond mutual funds and variables related to the overall risk and return on the market.

To measure the impact of risk and return variables on the flows to equity as well bond funds, we use regression analysis where the dependent variable is change in net cash flows to equity and bond funds respectively. Our control variables are: (1) the holding period return on the market portfolio; (2) standard deviation in returns on the market portfolio; (3) frequency of extreme days; (4) frequency of negative extreme days; (5) frequency of positive extreme days; and (6) a dummy variable which reflects the market condition of a bull (or bear) market.

In this analysis, our sample period is restricted (by data) to the period 2000-2007 and we use quarterly data. Data are from the Swedish Investment Fund Association (Fondbolagens Förening) and reflect total net flows into equity and bond (short- and long term) funds. Furthermore, we obtained data on these net flows separated by households and corporations. We are interested in examining the changes in the net cash flows into funds and the investment behaviour. Our control variables are lagged one quarter, net cash flows into the first quarter of a calendar year is matched against our control variables for the fourth quarter of the prior calendar year and so forth.

Table 6 presents the results of our regression models for aggregate net flows into equity and bond funds where we measure flows in million of Swedish crowns (mSEK). Our flow data are scaled by the market value of net assets in the mutual funds at the end of the prior quarter. First we report net inflows into equity funds (Column 1-4) and then for bond funds (Column 5-8). In Column (1) we show the impact of return, and standard deviation of returns on net cash flows and in Column (2) we add the variable frequency of extreme days and in Column (3) we show the frequency of extreme days separated into negative and positive 
fractions respectively. Finally, in Column (4), we add a dummy variable for bull (bear) market conditions which takes the value of 1 if the overall return on the market is greater (less) than $10 \%(-10 \%)$ and 0 otherwise. $^{6}$

For flows into equity funds, as reported in Column 1, we find a positive correlation for return and standard deviation, thus, high returns and standard deviation in returns are associated with an increase in flows into equity funds. We also find that the estimated negative coefficient on returns into bond funds and the positive coefficient on standard deviation are statistically insignificant. In other words, a higher market return in the previous quarter, on average, is indicative of a reduction of inflows to bond funds. As reported in Column (2), (3) and (4), the estimated coefficients for the frequency of extreme days are statistically insignificant and indicate that net inflows into equity funds are unrelated to the frequency, and the direction, of extreme day returns in the previous quarter. However, even if the estimated coefficients for the frequency of negative and positive extreme days are statistically insignificant, they may have an impact on flows to equity funds by different investors. The bond mutual fund results in Column (6), (7), and (8), show significant results for the negative and positive extreme days. The significant positive coefficients on frequency of negative extreme days and the two negative significant coefficients on the frequency of positive extreme days clearly show an impetus for net flows to move into bond mutual funds as more negative extreme days occur and out of bond mutual funds as more positive extreme days occur in a prior quarter. Our dummy variable, classifying if the previous quarter can be defined as a bull (bear) quarter (i.e., holding period return greater (less) than or equal to $10 \%$ $(-10 \%))$ has a negative sign for equity funds and indicates that a market return in excess of $10 \%$ will on average reduce flows into equity funds. The positive coefficient on the bear

\footnotetext{
${ }^{6}$ A time variable was also applied but was not statistically significant in any case.
} 
market dummy for the bond mutual funds indicates an increase in flows into bond funds. ${ }^{7}$ A time variable, to capture time trend, was incorporated into the models but due to complete non-significance was dropped. In summary, the analysis presented in Table 6 , that the net inflows to equity and bond funds in Sweden show mixed results in relation to the cornerstones in financial theory, risk and return. Total equity fund flows respond positively to the overall market return. Total bond fund flows did not respond in a significant manner to either risk or return. Instead, our data suggest a long-term investment strategy with regular contribution into equity and bond funds. Our results also suggest that the most important variable, related to net inflows to bond mutual funds, is whether the previous quarter reported a preponderance of either positive or negative extreme day returns. These results are based on the total net flows by individuals and corporations. The possibility exists that individuals and corporations may invest in a different manner of direction.

We now specify and re-examine flows into equity and bond funds where we control whether the investors is an individual or a corporation. As flows into funds by individuals usually are linked to various long-term saving products (e.g. pension schemes in a unit-link context) we predict no relationship between cash flows and risk metrics as savings by this group reflect a naïve investment strategy ("monthly saving schemes”). Furthermore, taxation of capital gains could restrict rebalancing of portfolios.

Table 7 shows the results of this investigation for individuals. For equity mutual funds, individual investors (households) react in a positive and significant way to return for all models. A higher prior quarter return induces more flow into equity mutual funds. Risk is not significant and is only reported in Column (1) for equity mutual funds. The frequency of extreme day returns is insignificant, as is the frequency of negative and positive extreme day returns in Column (2, 3 and 4). Extreme day market behaviour does not seem to impact the

\footnotetext{
${ }^{7}$ The switch in bull/bear market dummy variables is based on the better fit of the model. The bull and bear data are not mirror images because the range between $-10 \%$ and $10 \%$ are unaffected.
} 
flows into equity mutual funds by individual investors. Our dummy variable in Column (4), reflecting bull market, is negative but statistically insignificant ( $p$-value $=0.16$, not reported), and indicates that a bull market may reduce flows into equity funds when coupled with an increased frequency of extreme days. Furthermore, the addition of the dummy variable increases the $\mathrm{R}^{2}$ from $10.7 \%$ to $13.9 \%$. If a bear market dummy is the only independent variable, a negative significant estimated coefficient ( $p$-value $=0.08$, not reported) is estimated meaning a bear quarter leads to a reduction in subsequent flows to equity mutual funds.

For flows into bond funds, we obtain different results on return with no significant relationships for our models. In Column (6) the frequency of extreme days is negative but statistically insignificant $(t$-statistic $=-0.09)$. However, as reported in Column (7) and (8), negative extreme days will increase cash flows into bond funds; the estimated coefficients are statistically significant at the $1 \%$ and $5 \%$ level respectively. Positive extreme days will reduce cash flows into bond funds; these coefficient estimates are strong and statistically significant at the $1 \%$ and $5 \%$ level. The sign of the estimated coefficient reflecting a bull market in Column (8) is negative and of possible economic significance ( $p$-value $=0.12$, not reported). If a prior quarter market condition can be classified as a bull market, this suggests that cash flows into bond funds will decrease in the following quarter. The expectation may be that weak returns to the bond mutual funds will follow when the equity market is positive or strong. Note also that the $\mathrm{R}^{2}$ increases from $20.3 \%$ to $24.3 \%$ when we add this dummy variable. Individual investors are strongly influenced by the combination of negative and positive extreme days and the market condition. The total number of extreme days alone is insignificant but the estimated bull market coefficient (-0.0052) alone is statistically significant $(t$-statistic $=-2.35)$. 
Table 8 reports cross-sectional results of cash flows from corporations on our control variables. In this analysis we expect that corporations monitor risk as well as the composition of the overall portfolio in a more detailed way compared to individuals. For flows into equity funds, we document that negative (positive) extreme days indicates a decrease (increase) in cash flows to equity funds. When we add the dummy variable, reflecting a bull market, we see that it is positively correlated to cash flows, albeit not statistically significant. The explanatory power of the models, shown in Columns (1-4) for equity mutual funds flows by corporations is totally absent. Clearly, other explanations are possible and plausible. Corporations, if they have a longer investment horizon, may not be concerned by risk and volatility factors as much.

The net inflows to bond funds by corporations exhibit much of the same behaviour as equity fund flows with no significant response to risk or return. The net cash flow into bond funds is (insignificantly) negatively related to the total frequency of extreme days as shown in Column (6). In Column (7), the bond mutual fund flows is negatively (positively) correlated to frequency of negative (positive) extreme days. The market condition variable, bear (Column 8), will increase flows into bond funds as the estimated coefficient is statistically significant $(t$-statistic $=2.02)$. This is consistent with long held market belief that as market conditions weaken, capital is moved to fixed income. The last row in Table 8 reports the adjusted $\mathrm{R}^{2}$. As shown, when we add the dummy variable, the adjusted $\mathrm{R}^{2}$ increases to $9.8 \%$.

In summary, the lack of significance of various risk metrics on flows to equity and bond funds is somewhat surprising as our results indicate that Swedish individuals or corporations do not pay attention to this foundation in financial management. Return on the other hand does play a role for equity mutual fund flows and is primarily, if not wholly, driven by individuals. Thus, our empirical results are not fully consistent with prior literature (e.g. Jones et al. (2004)). This may be explained by the argument that a more active investment strategy, 
primarily for individuals, is hindered by tax-rules. Individuals continue to add to equity mutual funds with additions; mitigated by market returns, overall market characterization (bull or bear), influenced by extreme days activity but withdrawals may be negated by tax consequences. For corporations, the results suggests that a substantial swing in market behaviour through extreme returns (negative and positive) or market conditions (bull or bear) can cause a deviation from the strategic asset allocation weights, and hence, force a reshuffle in the total portfolio towards bonds.

\section{Conclusions}

We examine the relationship between the frequency of extreme days and changes in investor behaviour in Sweden. First, we examine the frequency of extreme date returns, defined as a trading day when the absolute logarithmic percentage change on the market return is equal to or greater than $1.5 \%$. We also investigate if these returns are correlated to stock market performance. For a sample of 17,733 observations of daily stock market return over the sample period 1939-2006, we find that the frequency of extreme day returns has increased over time. These results clearly indicate that the downside risk to all investors has increased over time. The relationship between the extreme date return and the stock market performance for the first five trading days following the extreme date is examined. For returns located in the lower tail, we find a negative correlation in the first two trading days after the extreme date. For returns located in the upper tail, no such relationship can be identified. We also find that the frequency of extreme date returns in a year is positively correlated to the frequency of extreme days the prior year. Moreover, we document that a prior bear market contributes to this volatility (albeit not generally statistically significant).

Second, we examine cash flows into equity and bond funds in aggregate but also separated into different investors (individuals and corporations). Our evidence on the relation 
between flows into equity and bond funds and several risk metrics are mixed as we in general are unable to obtain any statistically significant estimates on the risk measure, standard deviation, and primarily a positive response to return by individuals. As market participants, on average, change their investment behaviour following large increases in stock prices other forces must drive such changes.

The findings in this paper contribute to our understanding of how individual investors respond to returns but also to the volatility on the market. Specifically, we find that individual investors do not change their asset allocations for equity in response to the frequency of negative or positive extreme day returns. These far tail returns do have an impact on bond mutual fund allocation though; flows positively respond to the frequency of negative extreme day returns and negatively to positive extreme day returns in the stock market. One conclusion from our study, given our data and models, is that while individuals respond to market return behaviour, saving by individuals has a long-term investment horizon and the view of "dollar-cost-averaging". As some reallocation and rebalancing of funds occurs, more active rebalancing may be "fenced in" by tax rules. Investors are clearly impacted by risk in their decisions. The downside risk, to individual investors and the risk of loss to corporate bond fund investors, is evident in the signs of the funds flow. Our findings show that investors, individuals as well as corporations, use simple passive investment strategies and hence, do not believe in market timing or wish to endeavour capital on capturing far tail or black swan type returns. 


\section{References}

Barber, B. M. and T. Odean, 2002, “Online Investors: Do the Slow Die First?", Review of Financial Studies (15), 455-487.

Barberis, N., A. Schleifer, and R. Vishny, 1998, “A model of investor sentiment”, Journal of Financial Economics (49), 307-343.

Benartzi, S., and R. Thaler, 1995, "Myopic Loss Aversion and the Equity Premium Puzzle", Quarterly Journal of Economics (110), 73-92.

Bogle, J. C., 2008, “Black Monday and Black Swans”, Financial Analysts Journal (64), $30-40$.

De Bondt, W. F. M., and R. Thaler, 1985, “Does the Stock Market Overreact?”, Journal of Finance (40), 793-805.

De Bondt, W.F.M., 1998, “A portrait of the individual investor", European Economic Review (42), 831-844.

Estrada, J., 2008, "Investing in Emerging Markets: A Black Swan Perspective”, SSRN, http://ssrn.com/abstract=1308082.

Francis, J., R. La Fond, P.M. Olsson, and K. Schipper, 2004, "Cost of Equity and Earnings Attributes", Accounting Review (79), 967-1010.

French, K. R. and R. Roll, 1986, "Stock return variances: The Arrival of information and reaction of traders", Journal of Financial Economics (17), 5-26.

Grundy, B.D., and J.S. Martin, 2001, "Understanding the nature of the risks and the source of the rewards to momentum trading", Review of Financial Studies (14), 29-78.

Guo, B., and M. Darnell, 2005, "Time Diversification and Long-Term Asset Allocation", Journal of Wealth Management, Winter 2005, 65-76.

Hardouvelis, G.A. and P. Theodossiou, 2002, "The Asymmetric Relation Between Initial Margin Requirements and the Stock Market Volatility Across Bull and Bear Markets", Review of Financial Studies (15), 1525-1560.

Jegadeesh, N., and S. Titman, 2001, “Momentum”, Working paper, University of Illinois.

Jones, C. P. and J. W. Wilson, 2000, "Stock Returns in the 1990s: Implications for the Future”, Journal of Private Portfolio Management, Spring, 51-60.

Jones, C. P., M. D. Walker and J. W. Wilson., 2004, “Analyzing Stock Market Volatility using Extreme-Day Measures”, Journal of Financial Research (27), 585-601.

Lucas, A. and P. Klaassen, 1998, "Extreme Returns, Downside Risk, and Optimal Asset Allocation", Journal of Portfolio Management, Fall, 71-79. 
Mandlebrot, B., 1963, "The Variation of Certain Speculative Prices", Journal of Business (36), 394-419.

McEnally, R. W., and R.B. Todd, 1992, "Cross-Sectional Variation in Common Stock Returns”, Financial Analysts Journal (48-3), May/June, 59-64.

Odean, T., 1999, "Do Investors Trade Too Much?”, American Economic Review 89, 1279-1298.

Pactwa, T. and A. Prakash, 2004, "Using Extreme Value Theory to Value Stock Market Returns", Working Paper, Florida International University, Miami.

Schwert, G. W., 1989, "Why does stock market volatility change over times?", Journal of Finance (44), 1115-1153.

Schwert, G. W., 1998, "Stock market volatility: Ten years after the crash", National Bureau of Economic Research, Working Paper No. 6381.

Shefrin, H., and M. Statman, 1985, "The disposition to sell winners to early and ride the losers too long: Theory and evidence", Journal of Finance (40), 777-792.

Schiller, R. J., 1989, “Market Volatility”, Cambridge, MIT Press.

Veld, C., and Y. V. Veld-Merekoulova, 2008, "The risk perceptions of individual investors", Journal of Economic Psychology (29), 226-252.

Xu, Y., and B. G. Malkiel, 2003, "Investigating the Behavior of Idiosyncratic Volatility", Journal of Business (76), 613-644. 


\section{Figure 1 \\ Percentage of Extreme Days Returns \\ on the Stockholm Stock Exchange from 1939 to 2006}

This figure shows the development of extreme day returns on the Stockholm Stock Exchange from 1939 to 2006. An extreme day return is defined as a logarithmic percentage change less than or equal to $-1.5 \%$ or equal to or greater than $1.5 \%$. The percentage of extreme days is the ratio between total number of extreme days divided by trading days for each calendar year and expressed as a percentage. The median value of number of extreme days, illustrated by the solid line, is $4.43 \%$ for the full sample period.

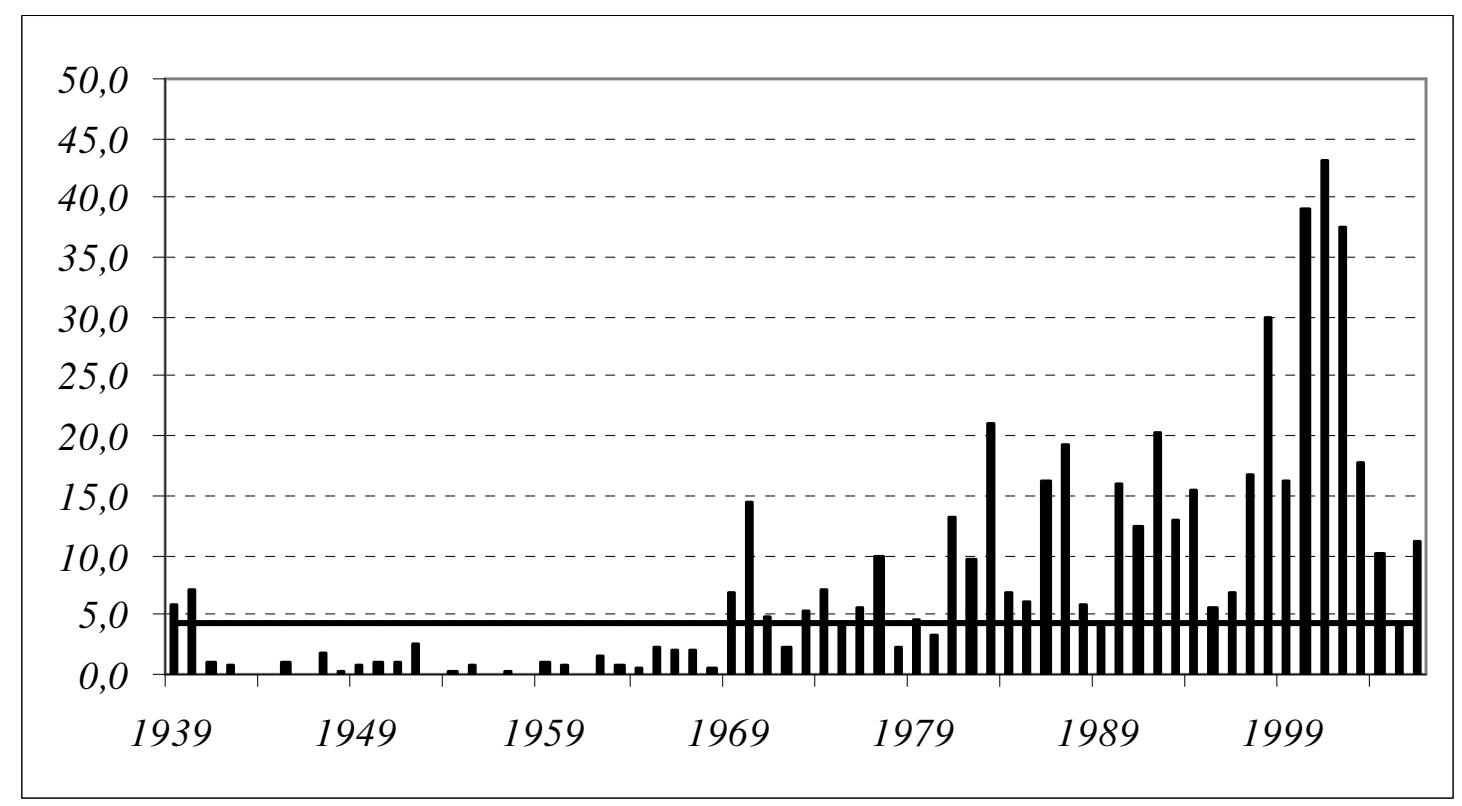


Figure 2

Percentage and Sign of Extreme Days Returns on the Stockholm Stock Exchange from 1939 to 2006

This figure shows the development of extreme day returns, defined as a daily logarithmic return equal to or less than $-1.5 \%$ or equal to or greater than $1.5 \%$ on the Stockholm Stock Exchange from 1939 to 2006 and its distribution into negative and positive values. In other words, this figure reflects the proportion of negative (below the zero-line) and positive (above the zero-line) extreme day returns from the bars in Figure 1.

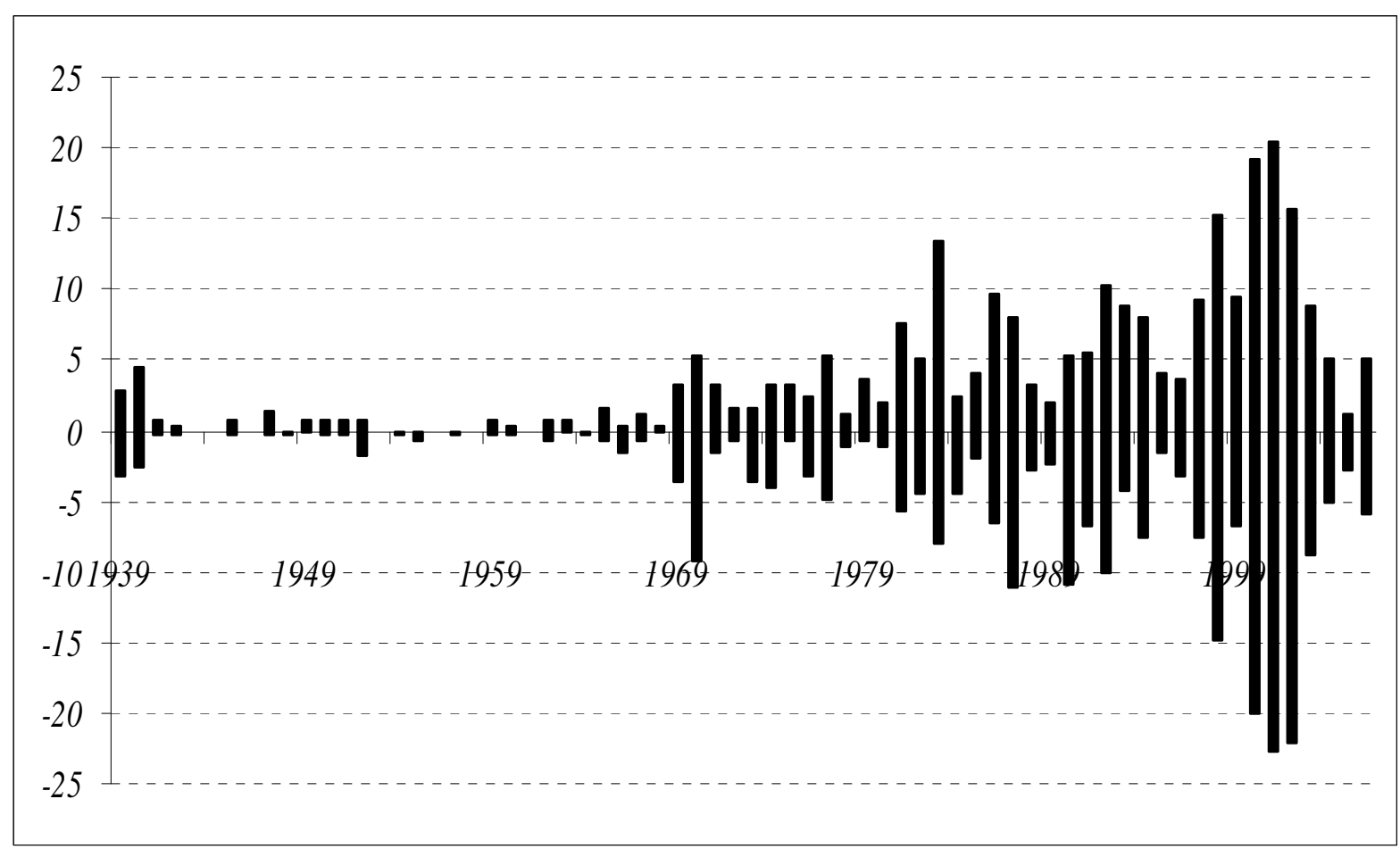


Table 1

Summary Statistics of Daily Returns on the Swedish Stock Market

Between 1939 and 2006

This table illustrates the summary statistics and the distribution of daily logarithmic percentage changes on the Stockholm Stock Exchange during 1939 to 2006. An extreme day return is defined as a daily logarithmic return less than or equal to $-1.5 \%$ (lower tail) or equal to or more than $1.5 \%$ (upper tail).

\begin{tabular}{|c|c|c|c|}
\hline \multicolumn{4}{|c|}{ Panel A Distribution of Daily Logarithmic Returns } \\
\hline Interval & Percent & & Cumulative Percent \\
\hline-3.00 or less & 0.67 & & 0.67 \\
\hline-3.00 to -2.50 & 0.42 & & 1.09 \\
\hline-2.50 to -2.00 & 0.79 & & 1.88 \\
\hline-2.00 to -1.50 & 1.79 & & 3.67 \\
\hline-1.50 to -1.0 & 3.85 & & 7.52 \\
\hline-1.0 to -0.50 & 10.67 & & 18.19 \\
\hline-0.50 to 0 & 26.93 & & 45.12 \\
\hline 0 to 0.50 & 33.69 & & 78.81 \\
\hline 0.50 to 1.00 & 12.53 & & 91.34 \\
\hline 1.00 to 1.50 & 4.91 & & 96.25 \\
\hline 1.50 to 2.00 & 2.04 & & 98.29 \\
\hline 2.50 to 3.00 & 0.82 & & 99.11 \\
\hline 3.00 or more & 0.90 & & 100.0 \\
\hline \multicolumn{4}{|c|}{ Panel B: Statistics of Daily Logarithmic Returns } \\
\hline & All observations & Lower tail & Upper tail \\
\hline Mean & 0.00033 & -0.02381 & 0.02279 \\
\hline Standard Deviation & 0.00875 & 0.01048 & 0.00970 \\
\hline Median & 0.00045 & -0.02011 & 0.01957 \\
\hline Skewness & -0.23650 & -2.62512 & 3.03101 \\
\hline Kurtosis & 10.73121 & 9.18102 & 8.32002 \\
\hline \# of Observations & 17,733 & 651 & 666 \\
\hline \multicolumn{4}{|c|}{ Panel C: Distribution of Daily Logarithmic Returns } \\
\hline Percentile & All observations & Lower tail & Upper tail \\
\hline $1 \%$ & -0.02471 & -0.07264 & 0.01503 \\
\hline $5 \%$ & -0.01239 & -0.04207 & 0.01535 \\
\hline $10 \%$ & -0.00826 & -0.03551 & 0.01569 \\
\hline $50 \%$ & 0.00045 & -0.02011 & 0.01957 \\
\hline $90 \%$ & 0.00909 & -0.01548 & 0.03380 \\
\hline $95 \%$ & 0.01327 & -0.01524 & 0.04035 \\
\hline $99 \%$ & 0.02490 & -0.01502 & 0.06302 \\
\hline
\end{tabular}


Table 2

\section{Frequency of Extreme Daily Returns on the Swedish Stock Market Between 1939 and 2006}

This table displays the distribution of extreme day returns over various periods (Panel A) as well as calendar months (Panel B) and weekdays (Panel C) on the Stockholm Stock Exchange from 1939 to 2006. An extreme day return is defined as a logarithmic percentage change less than or equal to $-1.5 \%$ (lower tail) or equal to or more than $1.5 \%$ (upper tail).

\begin{tabular}{|c|c|c|c|c|c|}
\hline \multicolumn{6}{|c|}{ Panel A: By Periods } \\
\hline Period & $\begin{array}{c}\% \text { of } \\
\text { Extreme } \\
\text { Returns }\end{array}$ & $\begin{array}{c}\text { Number of } \\
\text { Negative } \\
\text { Extreme returns }\end{array}$ & $\begin{array}{c}\text { Number of } \\
\text { Positive } \\
\text { Extreme returns }\end{array}$ & $\begin{array}{l}\text { Min. value } \\
\text { of } \\
\text { Extreme } \\
\text { Returns }\end{array}$ & $\begin{array}{l}\text { Max. value } \\
\text { of } \\
\text { Extreme } \\
\text { Returns }\end{array}$ \\
\hline $\begin{array}{l}1940-49 \\
1950-59 \\
1960-69 \\
1970-79 \\
1980-89 \\
1990-99 \\
2000-2006 \\
1939-2006\end{array}$ & $\begin{array}{c}1.24 \\
0.70 \\
1.68 \\
5.93 \\
10.47 \\
15.23 \\
20.43 \\
7.43 \\
\end{array}$ & $\begin{array}{c}12 \\
12 \\
21 \\
74 \\
119 \\
183 \\
219 \\
651 \\
\end{array}$ & $\begin{array}{c}23 \\
8 \\
22 \\
74 \\
141 \\
199 \\
140 \\
666 \\
\end{array}$ & $\begin{array}{l}-0.07716 \\
-0.04352 \\
-0.03362 \\
-0.04106 \\
-0.09144 \\
-0.07340 \\
-0.08318 \\
-0.09144 \\
\end{array}$ & $\begin{array}{l}0.03380 \\
0.02372 \\
0.02891 \\
0.05068 \\
0.08052 \\
0.09816 \\
0.07323 \\
0.09816 \\
\end{array}$ \\
\hline \multicolumn{6}{|c|}{ Panel B: By Calendar Months } \\
\hline $\begin{array}{l}\text { Calendar } \\
\text { Month }\end{array}$ & $\begin{array}{c}\% \text { of } \\
\text { Extreme } \\
\text { Returns }\end{array}$ & $\begin{array}{c}\text { Number of } \\
\text { Negative } \\
\text { Extreme returns }\end{array}$ & $\begin{array}{c}\text { Number of } \\
\text { Positive } \\
\text { Extreme returns }\end{array}$ & $\begin{array}{l}\text { Min. value } \\
\text { of } \\
\text { Extreme } \\
\text { Returns }\end{array}$ & $\begin{array}{l}\text { Max. value } \\
\text { of } \\
\text { Extreme } \\
\text { Returns }\end{array}$ \\
\hline $\begin{array}{l}\text { January } \\
\text { February } \\
\text { March } \\
\text { April } \\
\text { May } \\
\text { June } \\
\text { July } \\
\text { August } \\
\text { September } \\
\text { October } \\
\text { November } \\
\text { December }\end{array}$ & $\begin{array}{c}12.50 \\
7.58 \\
8.67 \\
7.73 \\
6.41 \\
5.00 \\
4.92 \\
7.97 \\
10.23 \\
10.78 \\
10.94 \\
7.27 \\
\end{array}$ & $\begin{array}{l}65 \\
39 \\
52 \\
49 \\
46 \\
33 \\
31 \\
58 \\
80 \\
71 \\
59 \\
46 \\
\end{array}$ & $\begin{array}{l}95 \\
58 \\
59 \\
50 \\
36 \\
31 \\
32 \\
44 \\
51 \\
66 \\
81 \\
47 \\
\end{array}$ & $\begin{array}{l}-0.06230 \\
-0.05422 \\
-0.06130 \\
-0.07717 \\
-0.03983 \\
-0.03894 \\
-0.04650 \\
-0.06619 \\
-0.08318 \\
-0.09144 \\
-0.05710 \\
-0.04685 \\
\end{array}$ & $\begin{array}{l}0.07180 \\
0.03421 \\
0.04252 \\
0.04891 \\
0.03579 \\
0.04174 \\
0.07323 \\
0.04630 \\
0.06302 \\
0.09816 \\
0.08431 \\
0.05068 \\
\end{array}$ \\
\hline \multicolumn{6}{|c|}{ Panel C: By Weekdays } \\
\hline Weekday & $\begin{array}{c}\% \text { of } \\
\text { Extreme } \\
\text { Returns }\end{array}$ & $\begin{array}{c}\text { Number of } \\
\text { Negative } \\
\text { Extreme returns }\end{array}$ & $\begin{array}{c}\text { Number of } \\
\text { Positive } \\
\text { Extreme returns }\end{array}$ & $\begin{array}{l}\text { Min. value } \\
\text { of } \\
\text { Extreme } \\
\text { Returns }\end{array}$ & $\begin{array}{l}\text { Max. value } \\
\text { of } \\
\text { Extreme } \\
\text { Returns }\end{array}$ \\
\hline Monday & 24.14 & 150 & 159 & -0.07758 & 0.09816 \\
\hline Tuesday & 20.55 & 137 & 126 & -0.08318 & 0.05928 \\
\hline Wednesday & 18.75 & 130 & 110 & -0.05872 & 0.06391 \\
\hline Thursday & 19.53 & 116 & 134 & -0.09144 & 0.07199 \\
\hline Friday & 16.72 & 95 & 119 & -0.04586 & 0.08431 \\
\hline Saturday & 0.31 & 1 & 3 & -0.01626 & 0.01947 \\
\hline
\end{tabular}


Table 3

Mean and Cumulative Stock Market Returns Following Extreme Dates

This table reports mean and median stock market returns and cumulative stock market returns (daily logarithmic percentage change) following an extreme day on the Stockholm Stock Exchange over the sample period 19392006 and two sub periods. An extreme day return is defined as a logarithmic percentage change less than or equal to $-1.5 \%$ (lower tail) or equal to or more than $1.5 \%$ (upper tail). ${ }^{*}, * * * * *$ denote significance at the $10 \%, 5 \%$, and $1 \%$ level, respectively.

Panel A: Daily Stock Market Returns following an Extreme Day, 1939-2006

\begin{tabular}{lcccc}
\hline & \multicolumn{2}{c}{ Lower Tail } & \multicolumn{2}{c}{ Upper Tail } \\
\cline { 2 - 5 } Days & Mean & Median & Mean & Median \\
\hline 1 & $-0.00142^{* *}$ & -0.00171 & $0.00319^{* * *}$ & 0.00334 \\
2 & $-0.00161^{*}$ & 0.00231 & $0.00024^{*}$ & 0.00053 \\
3 & 0.00102 & 0.00190 & 0.00041 & 0.00073 \\
4 & -0.00042 & 0.00012 & 0.00061 & 0.00113 \\
5 & -0.00033 & -0.00024 & 0.00081 & 0.00074 \\
\hline
\end{tabular}

Panel B: Daily Stock Market Returns following an Extreme Day, 1957-1981

\begin{tabular}{lcccc}
\hline & \multicolumn{2}{c}{ Lower Tail } & \multicolumn{2}{c}{ Upper Tail } \\
\cline { 2 - 5 } Days & Mean & Median & Mean & Median \\
\hline 1 & $-0.00202^{* * *}$ & -0.00190 & $0.00373 * * *$ & 0.00371 \\
2 & $0.00401 * * *$ & 0.00400 & $-0.00073 * *$ & -0.00052 \\
3 & 0.00061 & 0.00143 & 0.00033 & 0.00063 \\
4 & $-0.00130^{* * *}$ & 0.00012 & 0.00064 & 0.00084 \\
5 & $-0.00120^{* * *}$ & -0.00154 & 0.00054 & 0.00033 \\
\hline
\end{tabular}

Panel C: Daily Stock Market Returns following an Extreme Day, 1982-2006

\begin{tabular}{lcccc}
\hline & \multicolumn{2}{c}{ Lower Tail } & \multicolumn{2}{c}{ Upper Tail } \\
\cline { 2 - 5 } Days & Mean & Median & Mean & Median \\
\hline 1 & -0.00111 & -0.00102 & $0.00274^{* *}$ & 0.00304 \\
2 & 0.00101 & 0.00191 & 0.00064 & 0.00152 \\
3 & $0.00121^{*}$ & 0.00210 & 0.00054 & 0.00152 \\
4 & -0.00020 & 0.00052 & 0.00063 & 0.00141 \\
5 & 0.00012 & 0.00041 & 0.00090 & 0.00111 \\
\hline
\end{tabular}

Panel D: Mean (Median) Cumulative Stock Market Returns following an Extreme Day

\begin{tabular}{|c|c|c|c|c|c|c|}
\hline \multirow[b]{2}{*}{ Event Windows } & \multicolumn{2}{|c|}{$1939-2006$} & \multicolumn{2}{|c|}{$1957-1981$} & \multicolumn{2}{|c|}{$1982-2006$} \\
\hline & Lower Tail & Upper Tail & Lower Tail & $\begin{array}{c}\text { Upper } \\
\text { Tail } \\
\end{array}$ & Lower Tail & $\begin{array}{c}\text { Upper } \\
\text { Tail } \\
\end{array}$ \\
\hline$(0,10)$ & $\begin{array}{l}-0.02194 * * \\
(-0.01491)\end{array}$ & $\begin{array}{l}0.02912 * * \\
(0.02843)\end{array}$ & $\begin{array}{l}-0.02014 * * \\
(-0.01530)\end{array}$ & $\begin{array}{c}0.02773 * \\
(0.02874)\end{array}$ & $\begin{array}{l}-0.02184 * * * \\
(-0.01231)\end{array}$ & $\begin{array}{l}0.02990^{*} \\
(0.03112)\end{array}$ \\
\hline$(0,20)$ & $\begin{array}{l}-0.01854 * \\
(-0.00962)\end{array}$ & $\begin{array}{l}0.03562 * * \\
(0.03723)\end{array}$ & $\begin{array}{l}-0.01814 * * \\
(-0.01093)\end{array}$ & $\begin{array}{c}0.03313^{*} \\
(0.03794)\end{array}$ & $\begin{array}{c}-0.01724 * * \\
(-0.00463)\end{array}$ & $\begin{array}{l}0.03814 * * \\
(0.04203)\end{array}$ \\
\hline$(0,60)$ & $\begin{array}{c}0.00094 * \\
(0.01161)\end{array}$ & $\begin{array}{l}0.06074 * * \\
(0.07140)\end{array}$ & $\begin{array}{c}0.00675 * * \\
(-0.01313)\end{array}$ & $\begin{array}{c}0.03950^{*} \\
(0.04924)\end{array}$ & $\begin{array}{r}0.00314^{*} \\
(0.02233)\end{array}$ & $\begin{array}{r}0.07034 * \\
(0.09353)\end{array}$ \\
\hline
\end{tabular}




\section{Table 4 \\ Regression (OLS) Results and Extreme Day Returns on the Stockholm Stock Exchange from 1939 to 2006}

This table displays OLS-regression results following daily extreme returns. The dependent variable is the market return on the first up to the fifth trading day following the extreme date and the independent variable is the return on the extreme date. Results are presented for three different periods, 1939-2006, 1957-1981 and 1982-2006 and for each tail respectively.

* denote significance at the $5 \%$ level.

Panel A: Extreme Daily Returns, 1939-2006

\begin{tabular}{|c|c|c|c|c|c|c|c|c|c|c|}
\hline & \multicolumn{5}{|c|}{ Lower Tail } & \multicolumn{5}{|c|}{ Upper Tail } \\
\hline & $t+1$ & $t+2$ & $t+3$ & $t+4$ & $t+5$ & $t+1$ & $t+2$ & $t+3$ & $t+4$ & $t+5$ \\
\hline Intercept & $\begin{array}{l}-0.0080 * \\
(-4.50)\end{array}$ & $\begin{array}{l}-0.0019 \\
(-1.02)\end{array}$ & $\begin{array}{l}0.0028 \\
(1.58)\end{array}$ & $\begin{array}{l}-0.0021 \\
(-1.17)\end{array}$ & $\begin{array}{l}0.0030 \\
(1.74)\end{array}$ & $\begin{array}{l}0.0031 \\
(2.07)\end{array}$ & $\begin{array}{l}0.0005 \\
(0.36)\end{array}$ & $\begin{array}{l}0.0022 \\
(1.55)\end{array}$ & $\begin{array}{l}0.0004 \\
(0.26)\end{array}$ & $\begin{array}{l}0.0042 \\
(3.09)\end{array}$ \\
\hline Coefficient & $\begin{array}{l}-0.2774 * \\
(-4.08)\end{array}$ & $\begin{array}{l}-0.1446^{*} \\
(-2.07)\end{array}$ & $\begin{array}{l}0.0745 \\
(1.09)\end{array}$ & $\begin{array}{l}-0.0682 \\
(-1.01)\end{array}$ & $\begin{array}{l}0.1411^{*} \\
(2.11)\end{array}$ & $\begin{array}{l}0.0033 \\
(0.05)\end{array}$ & $\begin{array}{l}-0.0122 \\
(-0.23)\end{array}$ & $\begin{array}{l}-0.0809 \\
(-1.40)\end{array}$ & $\begin{array}{l}0.0088 \\
(0.16)\end{array}$ & $\begin{array}{l}-0.1519 * \\
(-2.76)\end{array}$ \\
\hline $\begin{array}{l}\text { F-value } \\
\text { R-sad }\end{array}$ & $\begin{array}{c}16.61 \\
0.03\end{array}$ & $\begin{array}{l}4.29 \\
0.01\end{array}$ & $\begin{array}{l}1.18 \\
0.00\end{array}$ & 1.02 & $\begin{array}{l}4.46 \\
0.01\end{array}$ & $\begin{array}{l}0.00 \\
0.00\end{array}$ & 0.05 & $\begin{array}{l}1.98 \\
0.00\end{array}$ & $\begin{array}{l}0.02 \\
0.00\end{array}$ & $\begin{array}{l}7.59 \\
0.01\end{array}$ \\
\hline
\end{tabular}

Panel B: Extreme Daily Returns, 1957-1981

\begin{tabular}{|c|c|c|c|c|c|c|c|c|c|c|}
\hline & \multicolumn{5}{|c|}{ Lower Tail } & \multicolumn{5}{|c|}{ Upper Tail } \\
\hline & $t+1$ & $t+2$ & $t+3$ & $t+4$ & $t+5$ & $t+1$ & $t+2$ & $t+3$ & $t+4$ & $t+5$ \\
\hline Intercept & $\begin{array}{l}-0.0084 * \\
(-2.35)\end{array}$ & $\begin{array}{l}-0.0034 \\
(-0.91)\end{array}$ & $\begin{array}{l}-0.0019 \\
(-0.45)\end{array}$ & $\begin{array}{l}-0.0026 \\
(-0.76)\end{array}$ & $\begin{array}{l}0.0002 \\
(0.06)\end{array}$ & $\begin{array}{l}0.0143 * \\
(4.04)\end{array}$ & $\begin{array}{l}0.0032 \\
(0.99)\end{array}$ & $\begin{array}{l}0.0067 \\
(1.70)\end{array}$ & $\begin{array}{l}0.0017 \\
(0.53)\end{array}$ & $\begin{array}{l}0.0016 \\
(0.45)\end{array}$ \\
\hline Coefficient & $\begin{array}{l}-0.3115 \\
(-1.86)\end{array}$ & $\begin{array}{l}-0.3577 * \\
(-2.05)\end{array}$ & $\begin{array}{l}-0.1212 \\
(-0.61)\end{array}$ & $\begin{array}{l}-0.0628 \\
(-0.40)\end{array}$ & $\begin{array}{l}0.0726 \\
(0.37)\end{array}$ & $\begin{array}{l}-0.5386^{*} \\
(-3.08)\end{array}$ & $\begin{array}{l}-0.2023 \\
(-1.25)\end{array}$ & $\begin{array}{l}-0.3276 \\
(-1.68)\end{array}$ & $\begin{array}{l}-0.0576 \\
(-0.36)\end{array}$ & $\begin{array}{l}-0.0560 \\
(-0.32)\end{array}$ \\
\hline F-value & 3.47 & 4.20 & 0.37 & 0.16 & 0.14 & 9.51 & 1.56 & 2.83 & 0.13 & 0.10 \\
\hline R-sqd & 0.03 & 0.04 & 0.00 & 0.00 & 0.00 & 0.07 & 0.01 & 0.02 & 0.00 & 0.01 \\
\hline
\end{tabular}

Panel C: Extreme Daily Returns, 1982-2006

\begin{tabular}{|c|c|c|c|c|c|c|c|c|c|c|}
\hline & \multicolumn{5}{|c|}{ Lower Tail } & \multicolumn{5}{|c|}{ Upper Tail } \\
\hline & $t+1$ & $t+2$ & $t+3$ & $t+4$ & $t+5$ & $t+1$ & $t+2$ & $t+3$ & $t+4$ & $t+5$ \\
\hline Intercept & $\begin{array}{l}-0.0074 * \\
(-3.45)\end{array}$ & $\begin{array}{l}-0.0030 \\
(-1.37)\end{array}$ & $\begin{array}{l}-0.0035 \\
(1.61)\end{array}$ & $\begin{array}{l}-0.0016 \\
(-0.75)\end{array}$ & $\begin{array}{l}0.0038 \\
(1.79)\end{array}$ & $\begin{array}{l}0.0017 \\
(0.94)\end{array}$ & $\begin{array}{l}0.0010 \\
(0.60)\end{array}$ & $\begin{array}{l}0.0026 \\
(1.54)\end{array}$ & $\begin{array}{l}0.0006 \\
(0.35)\end{array}$ & $\begin{array}{l}0.0048^{*} \\
(2.92)\end{array}$ \\
\hline Coefficient & $\begin{array}{l}-0.2588 * \\
(-3.24)\end{array}$ & $\begin{array}{l}-0.1636^{*} \\
(-1.98)\end{array}$ & $\begin{array}{l}0.0930 \\
(1.16)\end{array}$ & $\begin{array}{l}-0.0558 \\
(-0.70)\end{array}$ & $\begin{array}{l}0.1515 \\
(1.94)\end{array}$ & $\begin{array}{l}0.0426 \\
(0.63)\end{array}$ & $\begin{array}{l}-0.0173 \\
(-0.28)\end{array}$ & $\begin{array}{l}-0.0877 \\
(-1.36)\end{array}$ & $\begin{array}{l}0.0014 \\
(0.02)\end{array}$ & $\begin{array}{l}-0.1659 * \\
(-2.62)\end{array}$ \\
\hline $\begin{array}{l}\text { F-value } \\
\text { R-sqd }\end{array}$ & $\begin{array}{c}10.48 \\
0.02\end{array}$ & $\begin{array}{l}3.91 \\
0.01\end{array}$ & $\begin{array}{l}1.34 \\
0.00\end{array}$ & $\begin{array}{l}0.49 \\
0.00\end{array}$ & $\begin{array}{l}3.77 \\
0.01\end{array}$ & $\begin{array}{l}0.40 \\
0.00\end{array}$ & $\begin{array}{l}0.08 \\
0.00\end{array}$ & $\begin{array}{l}1.84 \\
0.00\end{array}$ & $\begin{array}{l}0.00 \\
0.00\end{array}$ & $\begin{array}{l}6.86 \\
0.01\end{array}$ \\
\hline
\end{tabular}




\section{Table 5}

\section{Regression (OLS) Results and Frequency of Extreme Day Returns on the Stockholm Stock Exchange from 1940 to 2006}

This table shows, for our overall sample period but also for three sub-periods, OLS-regression results where the dependent variable is the frequency of extreme days in year $t$ and the independent variable is the frequency of extreme days in year $t$ - 1 , model (2). The $t$-statistics are within parentheses and $*, * *, * * *$ denote significance at the $10 \%, 5 \%$ and $1 \%$ level. Thus our model is as follows:

$$
\text { Freq }_{X \text { days }, t}=a+b\left(\text { Freq }_{X \text { days }, t-1}\right)+e
$$

\begin{tabular}{|c|c|c|c|c|c|}
\hline Period & Obs. & $\begin{array}{l}\text { Intercept } \\
\quad(a)\end{array}$ & $\begin{array}{c}\text { Estimated } \\
\text { Slope } \\
\text { Coefficient } \\
(b) \\
\end{array}$ & $\mathrm{R}^{2}$ & F-value \\
\hline 1940-1961 & 22 & $\begin{array}{c}0.0039 \\
(1.16)\end{array}$ & $\begin{array}{c}0.4519 * * * \\
(2.91)\end{array}$ & 0.297 & 8.45 \\
\hline $1962-1983$ & 22 & $\begin{array}{c}0.0308^{*} \\
(1.93)\end{array}$ & $\begin{array}{c}0.5463^{* *} \\
(2.09)\end{array}$ & 0.180 & 4.38 \\
\hline 1984-2006 & 23 & $\begin{array}{c}0.0681^{*} \\
(1.89)\end{array}$ & $\begin{array}{c}0.5659 * * * \\
(3.14)\end{array}$ & 0.320 & 9.86 \\
\hline 1940-2006 & 67 & $\begin{array}{c}0.0196 * * \\
(1.96)\end{array}$ & $\begin{array}{c}0.7540^{* * * *} \\
\quad(9.25)\end{array}$ & 0.568 & 85.45 \\
\hline
\end{tabular}




\section{Table 6 \\ Regression (OLS) Results of Net Flows into Equity and Bond Funds}

This table displays OLS-regression results for the net inflows regressions for mutual funds, equity and bond respectively. The dependent variable is quarterly net flows as a percent of prior quarter end asset value for equity and bond mutual funds. The independent variables include: the return on the market, standard deviation in returns on the market, frequency of extreme days, frequency of negative extreme days, frequency of positive extreme days, a bull (bear) dummy variable with the value of 1 if the return in the previous quarter was equal to or higher (lower) than $10 \%(-10 \%)$ and zero otherwise. All control variables are lagged one quarter. The $t$ statistics are within parentheses and $*, * *, * *$ denote significance at the $10 \%, 5 \%$ and $1 \%$ level respectively.

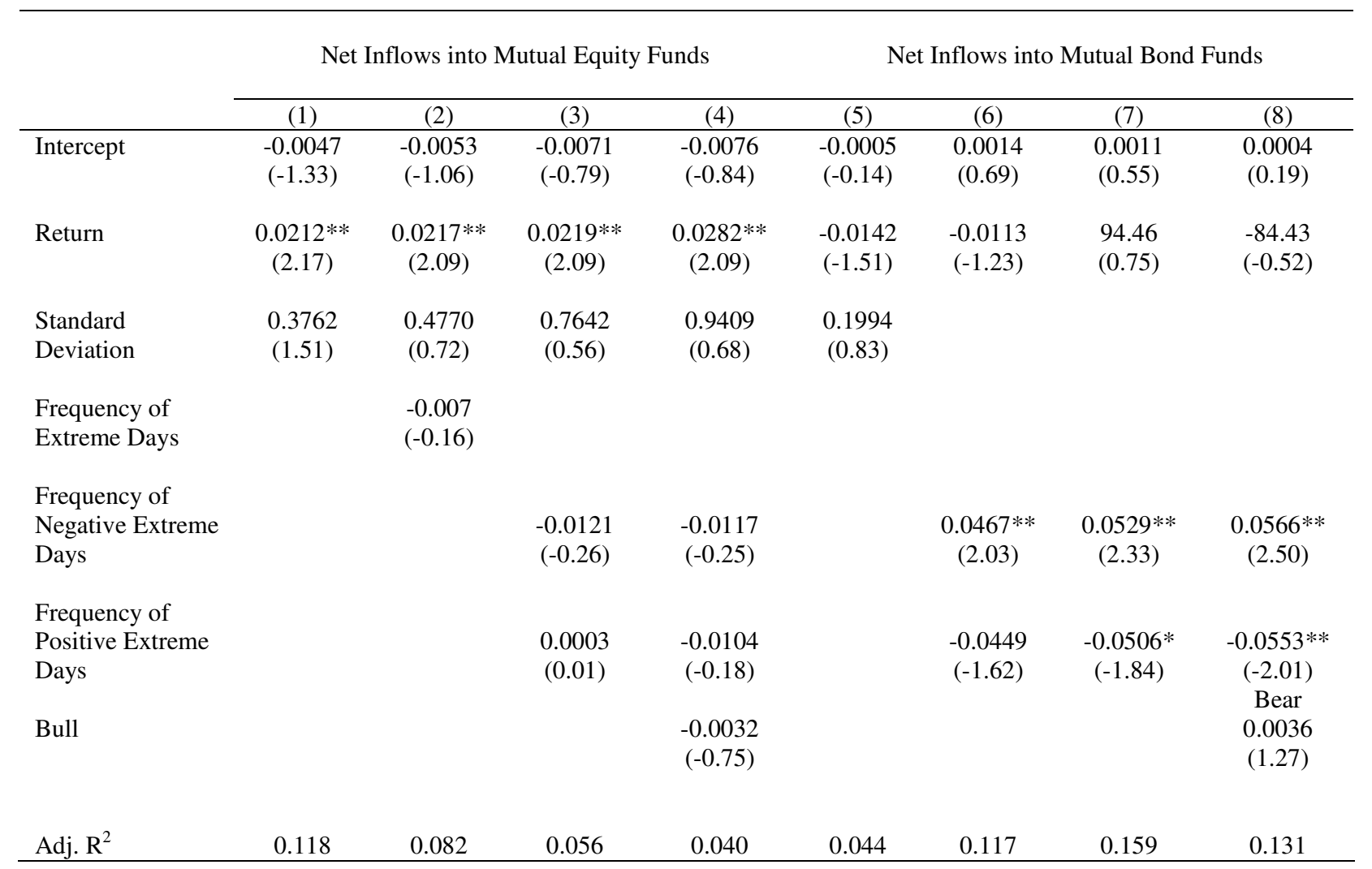




\section{Table 7 \\ Regression (OLS) Results of Net Flows into Equity and Bond Funds for Individuals}

This table displays OLS-regression results for the net inflows regressions for mutual funds, equity and bond respectively. The dependent variable is quarterly net flows as a percent of prior quarter end asset value for equity and bond mutual funds. The independent variables include: the return on the market, standard deviation in returns on the market, frequency of extreme days, frequency of negative extreme days, frequency of positive extreme days, a bull (bear) dummy variable with the value of 1 if the return in the previous quarter was equal to or higher (lower) than $10 \%(-10 \%)$ and zero otherwise. All control variables are lagged one quarter. The $t$ statistics are within parentheses and $*, * *, * *$ denote significance at the $10 \%, 5 \%$ and $1 \%$ level respectively.

\begin{tabular}{|c|c|c|c|c|c|c|c|c|}
\hline & \multicolumn{4}{|c|}{ Net Inflows into Mutual Equity Funds } & \multicolumn{4}{|c|}{ Net Inflows into Mutual Bond Funds } \\
\hline & (1) & (2) & (3) & (4) & (5) & (6) & (7) & (8) \\
\hline Intercept & $\begin{array}{c}-0.0058 * * \\
(-2.39)\end{array}$ & $\begin{array}{c}-0.0042 * * * \\
(-2.83)\end{array}$ & $\begin{array}{c}-0.0041 * * \\
(-2.69)\end{array}$ & $\begin{array}{c}-0.0034^{* *} \\
(-2.15)\end{array}$ & $\begin{array}{c}-0.0008 \\
(-0.29)\end{array}$ & $\begin{array}{c}-0.0014 \\
(-0.21)\end{array}$ & $\begin{array}{c}0.0000 \\
(0.06)\end{array}$ & $\begin{array}{c}0.0009 \\
(0.56)\end{array}$ \\
\hline Return & $\begin{array}{c}0.0163 * * \\
(2.41)\end{array}$ & $\begin{array}{c}0.0157 * * \\
(2.33)\end{array}$ & $\begin{array}{c}0.0164 * * \\
(2.36)\end{array}$ & $\begin{array}{c}0.0237 * * * \\
(2.77)\end{array}$ & $\begin{array}{c}-0.0111 \\
(-1.47)\end{array}$ & $\begin{array}{c}-0.0110 \\
(-1.37)\end{array}$ & $\begin{array}{l}42.29 \\
(0.35)\end{array}$ & $\begin{array}{c}-113.74 \\
(-0.70)\end{array}$ \\
\hline $\begin{array}{l}\text { Standard } \\
\text { Deviation }\end{array}$ & $\begin{array}{c}0.2409 \\
(1.39)\end{array}$ & & & & $\begin{array}{c}0.0785 \\
(0.41)\end{array}$ & $\begin{array}{c}0.1720 \\
(0.17)\end{array}$ & & \\
\hline $\begin{array}{l}\text { Frequency } \\
\text { of Extreme } \\
\text { Days }\end{array}$ & & $\begin{array}{c}0.0068 \\
(1.30)\end{array}$ & & & & $\begin{array}{c}-0.0029 \\
(-0.09)\end{array}$ & & \\
\hline $\begin{array}{l}\text { Frequency } \\
\text { of Negative } \\
\text { Extreme } \\
\text { Days }\end{array}$ & & & $\begin{array}{l}0.0153 \\
(0.887)\end{array}$ & $\begin{array}{c}0.0094 \\
(0.53)\end{array}$ & & & $\begin{array}{c}0.0530 * * * \\
(3.12)\end{array}$ & $\begin{array}{c}0.0443 * * \\
(2.54)\end{array}$ \\
\hline $\begin{array}{l}\text { Frequency } \\
\text { of Positive } \\
\text { Extreme } \\
\text { Days }\end{array}$ & & & $\begin{array}{c}-0.0035 \\
(-0.17)\end{array}$ & $\begin{array}{c}0.0034 \\
(0.16)\end{array}$ & & & $\begin{array}{l}-0.0583 * * * \\
(-2.83)\end{array}$ & $\begin{array}{l}-0.0490 \text { **** } \\
(-2.34)\end{array}$ \\
\hline Bull & & & & $\begin{array}{c}-0.0040^{8} \\
(-1.43)\end{array}$ & & & & $\begin{array}{c}-0.0052 \text { *** } \\
(-2.35)\end{array}$ \\
\hline Adj. $R^{2}$ & 0.137 & 0.130 & 0.107 & 0.139 & 0.017 & -0.017 & 0.203 & 0.243 \\
\hline
\end{tabular}

\footnotetext{
${ }^{8}$ In a similar model without the market return and with the use of the bear dummy variable, it becomes significant at the $10 \%$ level. On bond mutual funds the bear dummy is insignificant and the estimated coefficient for the frequency of extreme days are approximately the same as reported in Column (3).
} 


\section{Table 8 \\ Regression (OLS) Results of Net Flows into Equity and Bond Funds for Corporations}

This table displays OLS-regression results for the net inflows regressions for mutual funds, equity and bond respectively. The dependent variable is quarterly net flows as a percent of prior quarter end asset value for equity and bond mutual funds. The independent variables include: the return on the market, standard deviation in returns on the market, frequency of extreme days, frequency of negative extreme days, frequency of positive extreme days, a bull (bear) dummy variable with the value of 1 if the return in the previous quarter was equal to or higher (lower) than $10 \%(-10 \%)$ and zero otherwise. All control variables are lagged one quarter. The $t$ statistics are within parentheses and $*, * *, * * *$ denote significance at the $10 \%, 5 \%$ and $1 \%$ level respectively.

\begin{tabular}{|c|c|c|c|c|c|c|c|c|}
\hline & \multicolumn{4}{|c|}{ Net Inflows into Mutual Equity Funds } & \multicolumn{4}{|c|}{ Net Inflows into Mutual Bond Funds } \\
\hline & (1) & (2) & (3) & (4) & (5) & (6) & (7) & $(8)$ \\
\hline Intercept & $\begin{array}{l}0.0011 \\
(0.65)\end{array}$ & $\begin{array}{c}0.0020^{*} \\
(1.90)\end{array}$ & $\begin{array}{c}0.0019^{*} \\
(1.77)\end{array}$ & $\begin{array}{l}0.0017 \\
(1.48)\end{array}$ & $\begin{array}{c}0.0003 \\
(0.21)\end{array}$ & $\begin{array}{c}-0.0021 \\
(-0.59)\end{array}$ & $\begin{array}{c}0.0010 \\
(1.11)\end{array}$ & $\begin{array}{l}0.0006 \\
(0.62)\end{array}$ \\
\hline Return & $\begin{array}{c}0.0049 \\
(1.03)\end{array}$ & $\begin{array}{c}0.0047 \\
(0.97)\end{array}$ & $\begin{array}{c}0.0041 \\
(0.83)\end{array}$ & $\begin{array}{c}0.0019 \\
(0.31)\end{array}$ & $\begin{array}{c}0.1209 \\
(1.16)\end{array}$ & $\begin{array}{c}-0.0023 \\
(-0.54)\end{array}$ & $\begin{array}{c}-6.45 \\
(-0.18)\end{array}$ & \\
\hline $\begin{array}{l}\text { Standard } \\
\text { Deviation }\end{array}$ & $\begin{array}{c}0.1353 \\
(1.10)\end{array}$ & & & & $\begin{array}{c}-0.0031 \\
(-0.75)\end{array}$ & $\begin{array}{c}0.5172 \\
(0.95)\end{array}$ & & \\
\hline $\begin{array}{l}\text { Frequency of } \\
\text { Extreme Days }\end{array}$ & & $\begin{array}{c}0.0039 \\
(1.05)\end{array}$ & & & & $\begin{array}{c}-0.0122 \\
(-0.74)\end{array}$ & & \\
\hline $\begin{array}{l}\text { Frequency of } \\
\text { Negative Extreme } \\
\text { Days }\end{array}$ & & & $\begin{array}{c}-0.0023 \\
(-0.19)\end{array}$ & $\begin{array}{c}-0.0006 \\
(-0.04)\end{array}$ & & & $\begin{array}{c}-0.0000 \\
(-0.01)\end{array}$ & $\begin{array}{c}0.0033 \\
(1.12)\end{array}$ \\
\hline $\begin{array}{l}\text { Frequency of } \\
\text { Positive Extreme } \\
\text { Days }\end{array}$ & & & $\begin{array}{c}0.0116 \\
(0.78)\end{array}$ & $\begin{array}{l}0.0095 \\
(0.62)\end{array}$ & & & $\begin{array}{c}0.0077 \\
(0.61)\end{array}$ & \\
\hline Bull & & & & $\begin{array}{c}0.0012^{9} \\
(0.59)\end{array}$ & & & & $\begin{array}{c}\text { Bear }^{10} \\
0.0025^{* *} \\
(2.02)\end{array}$ \\
\hline Adj. $R^{2}$ & -0.001 & -0.004 & -0.029 & -0.054 & 0.007 & -0.009 & -0.025 & 0.098 \\
\hline
\end{tabular}

\footnotetext{
${ }^{9}$ Corporate net inflows into equity mutual funds had no better relationship if the bear dummy is used.

${ }^{10}$ None of total frequency of extreme days, negative or positive extreme days nor a bull dummy are significant for bond mutual funds. The bear dummy variable is statistically significant in a combination or as a sole independent variable.
} 